\title{
Combined effect of microbial inoculants on the quality of beetroot
}

J. AJAY KUMAR*, K.R. SREERAMULU AND G. KUSHALA ${ }^{1}$

Department of Agricultural Microbiology, University of Agricultural Sciences, G.K.V.K, BENGALURU (KARNATAKA) INDIA

${ }^{1}$ Department of Horticulture, University of Agricultural Sciences, G.K.V.K, BENGALURU (KARNATAKA) INDIA

\section{ARITCLE INFO}

Received : 29.09 .2014

Revised : 07.09 .2015

Accepted : 22.09.2015

\section{KEY WORDS :}

Microbial inoculants, Beetroot

*Corresponding author:

\section{ABSTRACT}

The highest total soluble solids (TSS) was observed in the tubers of plants provided with 75 per cent N, P plus 100 per cent K with microbial consortia of Azotobacter chroococcum, Glucanobacter diazotrophicus, Bacillus megaterium and Trichoderma harzianum $\left(\mathrm{T}_{10}\right)$. The lowest TSS was observed in the tubers of control plants. In general plants treated with combined microbial inoculation showed better plant nutrient uptake than untreated plants. Maximum total uptake of $\mathrm{N}$ and $\mathrm{P}$ was recorded in the plants provided with 75 per cent $\mathrm{N}, \mathrm{P}$ plus full dose of $\mathrm{K}$ with combined inoculation of Azotobacter chroococcum, Glucanobacter diazotrophicus, Bacillus megaterium and Trichoderma harzianum.

How to view point the article : Kumar, J. Ajay, Sreeramulu, K.R. and Kushala, G. (2015). Combined effect of microbial inoculants on the quality of beetroot. Internat. J. Plant Protec., 8(2): 364-367. 